\title{
A case of severe gout: A differential diagnosis
}

\author{
Costantino Caroselli1 10 , Guglielmo Bruno² \\ ${ }^{1}$ IRCCS-INRCA, Acute Geriatric Unit, Geriatric Emergency Room and Aging Research Centre, Ancona, Italy \\ ${ }^{2}$ Policlinico Sant'Andrea, Facoltà di Medicina e Psicologia, "Sapienza, Medicina Interna, Roma, Italy
}

Gout is an inflammatory arthritis caused by chronic hyperuricemia. This arthritis is due to deposition of monosodium urate crystals in and around joints and connective tissue. ${ }^{1}$

Previously were described four different clinical phases of gout progression: ${ }^{2}$

- Asymptomatic patients with serological findings of hyperuricemia

- Acute gouty arthritis

- Intercritical gout

- Chronic tophaceous gout: in this final phase, there is permanent damage and it is possible to find chronic synovitis, bone erosion, and sometimes cartilage or tendon damage and it is mostly characterized by the presence of tophi ${ }^{3}$ composed of urate crystals piled up in soft tissue and joints. Poor or inadequate control of the disease leads to destruction.

A 77-year-old female patient, coming from a rural area, was admitted to our Emergency Department with a 15-year long history concerning a progressive functional decline of the movement and pain worsening of hand fingers. On physical examination she had marked interphalangeal joints swelling, pain, and deformity (Figure 1). Otherwise, her medical and family histories were unremarkable, she did not receive any drug or over-the-counter medication, she denied the use of recreational drugs but admitted that she often used to drink alcohol, mostly beer and her diet included meat at least two to three times per week that could have caused her to develop gout. Laboratory tests showed increased serum urate level as $510 \mathrm{mmol} / \mathrm{L}$ (normal values [NV] 89.22-339.04 $\mathrm{mmol} / \mathrm{L}$ ), erythrocyte sedimentation rate as $30 \mathrm{~mm} / \mathrm{h}$ (NV 0-13) and C-reactive protein as $10.6 \mathrm{mg} / \mathrm{dL}$ (NV $0.5-1 \mathrm{mg} / \mathrm{dL}$ ). The other routine laboratory

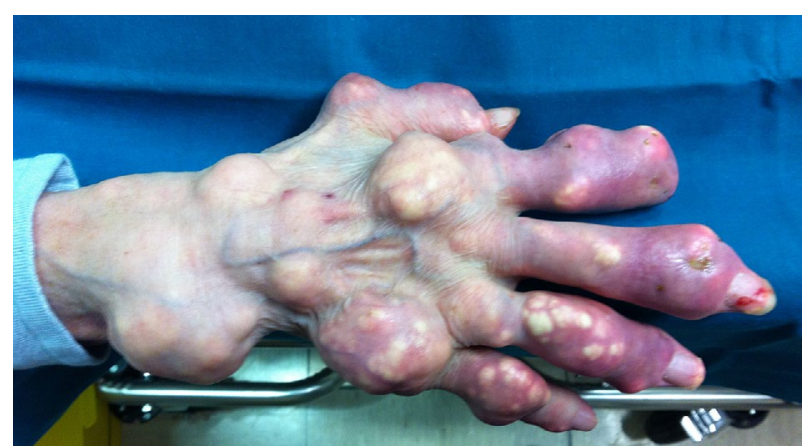

Figure 1. Severe tophaceous gout with large tophi deforming the hand fingers.

Received: June 28, 2020 Accepted: August 08, 2020 Published online: January 14, 2021

Correspondence: Costantino Caroselli, MD. INRCA-IRCCS, Acute Geriatric Unit, Geriatric Emergency Room and Aging Research Centre, 60127 Ancona, Italy. Tel: +390718003502 e-mail: costantinocost@yahoo.it 
findings, including hemochrome, platelet count, kidney and liver function blood test, electrolytes, and clotting system (prothrombin, thromboplastin and clottable fibrinogen) were within normal range. Differential diagnosis permitted to exclude rheumatoid arthritis because it is a polyarticular disease and spares the distal interphalangeal joints: additionally, the patient was anti-citrullinated protein antibody-negative. Psoriatic arthritis was not considered because it generally involves only the distal interphalangeal joints. Osteoarthritis (OA) was excluded as well because the American College of Rheumatology criteria for hand OA diagnosis were not respected. ${ }^{4}$ Besides, causes of metabolic OA associated with metabolic syndrome such as overweight, ${ }^{5}$ dyslipidemia, ${ }^{6}$ hyperglycemia, ${ }^{7}$ and vitamin $\mathrm{D}$ deficiency ${ }^{8}$ were excluded since the patient did not present these key components of metabolic OA. A written informed consent was obtained from the patient.

Calcium pyrophosphate dihydrate arthritis, ${ }^{9}$ also called pseudogout, was excluded because aspiration and synovial fluid analysis did not reveal the characteristic presence of calcium pyrophosphate dihydrate crystal. Arthritis associated with calcium phosphate crystals (generally hydroxyapatite) or calcium oxalate crystals ${ }^{10}$ was excluded for the absence of crystals in synovial fluid.

Moreover, our patient met the criteria for the diagnosis and investigation of gout ${ }^{11}$ and synovial fluid analysis permitted the identification of the characteristic monosodium urate crystals in joint fluid. Although the diagnostic utility of measuring uric acid level is limited, ${ }^{12}$ our patient had high value of serum urate level.

This report shows a case of severe gout arthritis in a patient who did not undergo general medical or rheumatological examination for many years. Our patient decided to apply to the hospital because pain and functional impotence of the hand fingers were becoming increasingly severe. Consequently, we found ourselves before a case of severe untreated gout.

Conventional X-rays are frequently used for the diagnosis and follow-up of gout while our patient refused to undergo X-ray investigation due to her fear of radiation although we explained that the radiation level she would be exposed to would be low. ${ }^{13}$ Although the patient refused to undergo hand X-rays, physical examination in association with synovial fluid analysis and serum urate levels permitted us to establish the diagnosis of gout.

\section{Acknowledgements}

We thank Dr. Eliana Viola for her careful English revision and Giuseppe Mazzone for picture collection.

\section{Declaration of conflicting interests}

The authors declared no conflicts of interest with respect to the authorship and/or publication of this article.

\section{Funding}

The authors received no financial support for the research and/or authorship of this article.

\section{REFERENCES}

1. Altman R, Alarcón G, Appelrouth D, Bloch D, Borenstein D, Brandt $\mathrm{K}$, et al. The American College of Rheumatology criteria for the classification and reporting of osteoarthritis of the hand. Arthritis Rheum 1990;33:1601-10.

2. Zhang W, Doherty M, Pascual E, Bardin T, Barskova $\mathrm{V}$, Conaghan $\mathrm{P}$, et al. EULAR evidence based recommendations for gout. Part I: Diagnosis. Report of a task force of the Standing Committee for International Clinical Studies Including Therapeutics (ESCISIT). Ann Rheum Dis 2006;65:1301-11.

3. Schlesinger N. Diagnosing and treating gout: a review to aid primary care physicians. Postgrad Med 2010;122:157-61.

4. Aşkın A, İnci R, Akan Ö, Demirdal S, Bayram K. A rare cause of knee pain in gout patients: tophi of patella. Arch Rheumatol 2015;30:71-4.

5. Gómez R, Conde J, Scotece M, Gómez-Reino JJ, Lago F, Gualillo O. What's new in our understanding of the role of adipokines in rheumatic diseases? Nat Rev Rheumatol 2011;7:528-36.

6. Gkretsi V, Simopoulou T, Tsezou A. Lipid metabolism and osteoarthritis: lessons from atherosclerosis. Prog Lipid Res 2011;50:133-40.

7. Hiraiwa $H$, Sakai $T$, Mitsuyama $H$, Hamada $T$, Yamamoto R, Omachi $\mathrm{T}$, et al. Inflammatory effect of advanced glycation end products on human meniscal cells from osteoarthritic knees. Inflamm Res 2011;60:1039-48.

8. Heidari B, Heidari P, Hajian-Tilaki K. Association between serum vitamin $\mathrm{D}$ deficiency and knee osteoarthritis. Int Orthop 2011;35:1627-31.

9. McCarty DJ, Kohn NN, Faires JS. The significance of calcium phosphate crystals in the synovial fluid of arthritis patients: The "pseudogout syndrome": I. Clinical aspects. Ann Intern Med 1962;56:711. 
10. Agudelo CA, Wise CM. Crystal-associated arthritis in the elderly. Rheum Dis Clin North Am 2000;26:527-46.

11. Harris MD, Siegel LB, Alloway JA. Gout and hyperuricemia. Am Fam Physician 1999;59:925-34.

12. Ragab G, Elshahaly M, Bardin T. Gout: An old disease in new perspective - A review. $\mathrm{J}$ Adv Res 2017;8:495-511.

13. Durcan L, Grainger R, Keen HI, Taylor WJ, Dalbeth $\mathrm{N}$. Imaging as a potential outcome measure in gout studies: A systematic literature review. Semin Arthritis Rheum 2016;45:570-9. 